\title{
Descentralización fiscal subnacional en Argentina, período 2005-2017. Desequilibrio fiscal vertical, autonomía y dependencia fiscales de la jurisdicción municipal
}

Subnational fiscal decentralization in Argentina between 2005 and 2017. Vertical fiscal imbalance, autonomy and fiscal dependency of the municipal jurisdiction Descentralização fiscal subnacional na Argentina, período de 2005 a 2017. Desequilíbrio fiscal vertical, autonomia tributária e dependência da jurisdição municipal

\section{Soledad Inés Herrera}

Universidad Nacional del Comahue -

Universidad Nacional de Río Negro, Argentina

E-mail: soledad.herrera@curza.uncoma.edu.ar

Fecha de recepción: 22/02/2020 Fecha de aceptación: 14/12/2020
Palabras clave

- Descentralización fiscal municipal

- Argentina

- Indicadores

- Desequilibrio fiscal vertical

- Dependencia fiscal

\section{Resumen}

La república Argentina tiene un gobierno federal, multijurisdiccional y con un mecanismo de coordinación financiera de coparticipación de impuestos. En ese marco, el presente trabajo pretende contribuir empíricamente al estudio de las relaciones fiscales subnacionales durante los años 2005-2017 y de la descentralización fiscal municipal en particular.

La investigación de tipo descriptivo se basa en datos del esquema Ahorro-Inversión-Financiamiento de la Administración Pública no financiera, publicados por el Ministerio de Economía de la Nación. En una primera instancia, aborda algunas consideraciones teóricas de la literatura del federalismo fiscal sobre descentralización fiscal y las implicancias de la diferenciación conceptual entre asimetría y desequilibrio fiscal vertical. Luego, se detallan aspectos metodológicos de la investigación y de las medidas de descentralización, autonomía y dependencia fiscales utilizadas.

Los resultados cuantitativos del análisis empírico referido al período 2005-2017 permiten afirmar que existe una marcada concentración de ingresos en el nivel provincial y una mayor descentralización del gasto 
público hacia la Jurisdicción municipal, tal como sucede en la relación fiscal Nación-Provincia. Además y específicamente para el nivel municipal, se observa un permanente desequilibrio fiscal vertical, ya que las transferencias fiscales de origen nacional y provincial no resuelven la asimetría fiscal de esa jurisdicción. Asimismo, la autonomía o correspondencia fiscal municipal es baja y la dependencia de las transferencias fiscales es alta como así también heterogénea entre las provincias.

Por último y con base en los resultados, se reflexiona sobre algunos aspectos de diseño del federalismo fiscal y los municipios.

\section{Abstract}

Argentina has a federal, multi-jurisdictional government with a financial coordination mechanism of tax joint participation. This paper aims to contribute empirically to the analysis of subnational fiscal relations between the years 2005-2017 and specifically to the analysis of the municipal fiscal decentralization.

The descriptive investigation is based on data from the Saving - Investment - Non-Financial Public Administration Financing scheme, published by the Argentinian Ministry of Economy. First, it deals with some theories related to fiscal federalism and fiscal decentralization and the implications of the conceptual differentiation between asymmetry and vertical fiscal imbalance. Second, methodological aspects of the research and of the policies of decentralization, autonomy and fiscal dependence are dealt with.

The quantitative results of the empirical analysis referring to the period 2005 - 2017 show a strong concentration of income at the provincial level and a greater decentralization of public spending towards municipal jurisdiction, as it happens in the Nation-Province fiscal relation.

In addition, and specifically for the municipal level, a permanent vertical fiscal imbalance is observed, since fiscal transfers of national and provincial origin do not resolve the fiscal asymmetry of that jurisdiction.

Keywords

- Municipal Fiscal Decentralization

- Argentina

- Indicator

- Vertical fiscal imbalance

- Fiscal Dependency Likewise, the autonomy or municipal fiscal correspondence was low, while its dependence on fiscal transfers was high and heterogeneous among the municipal public sector consolidated by provinces. Finally, and based on the results, some aspects of the design of fiscal federalism and municipalities will be reflected upon.

\section{Resumo}

A República Argentina possui um governo federal, multi-jurisdicional e com um mecanismo de coordenação financeira para a coparticipação tributária. Nesse contexto, o presente trabalho pretende contribuir empiricamente ao estudo das relações fiscais subnacionais durante os anos de 2005-2017 e da Descentralização fiscal municipal em particular. 
Palavras-chave

- Descentralização fiscal municipal

- Argentina

- Indicadores

- Desequilíbrio fiscal vertical

- Dependência fiscal
A pesquisa do tipo descritiva é baseada em dados do esquema Poupança - Investimento - Financiamento da Administração Pública Não Financeira, publicados pelo Ministério da Economia da Nação. Em um primeiro momento, aborda algumas considerações teóricas da literatura do Federalismo Fiscal sobre Descentralização Fiscal e as implicações da diferenciação conceitual entre Assimetria e Desequilíbrio fiscal vertical. Em seguida, são detalhados os aspectos metodológicos da investigação e das medidas de Descentralização, Autonomia e Dependência fiscal utilizadas.

Os resultados quantitativos da análise empírica referente ao período 2005 - 2017, permitem afirmar que há uma acentuada concentração de renda no nível provincial e uma maior descentralização da despesa pública para a jurisdição municipal, tal como acontece na relação fiscal Nação-Província. Aliás, e, especificamente para o nível municipal, observa-se um permanente Desequilíbrio fiscal vertical, uma vez que as transferências fiscais de origem nacional e provincial não resolvem a Assimetria fiscal dessa jurisdição. De igual modo, a Autonomia ou Correspondência fiscal municipal é baixa e a dependência das transferências fiscais é alta e heterogênea entre as províncias. Finalmente e com base nos resultados, reflete-se sobre alguns aspectos do desenho do Federalismo Fiscal e os Municípios. 